ORIGINAL ARTICLE

\title{
Evaluation of forest inventory processes in a forest under concession in the southwestern Brazilian Amazon
}

\author{
Felipe KAUAI*, Ana Paula Dalla CORTE, Vinicius CYSNEIROS, Allan Libanio PELISSARI, \\ Carlos Roberto SANQUETTA \\ Universidade Federal do Paraná - UFPR, Departamento de Ciências Florestais, Av. Lothário Meissner, 632, CEP 80210-170, Curitiba, Brasil. \\ * Corresponding author: kauaifex@gmail.com
}

\begin{abstract}
Forest inventory procedures are of utmost importance to studies of wood volume stocks, and forest structure and diversity, which provide relevant information to public policies, management plans and ecological research. The present work focused on the performance of inventory techniques in the Amazon region to evaluate wood volume stocks with higher levels of accuracy while maintaining sampling intensity fixed. Two sampling processes were assessed: simple random sampling and two-stage cluster sampling. The processes were evaluated through the allocation of sampling units with different dimensions, and the effectiveness of the generated estimators was analyzed as a function of stand density and basal area. Simple random sampling resulted in the smallest errors, reaching $9 \%$ when all species were sampled together. The method depicted forest phytosociological parameters with greater sensitivity, whereas two-stage cluster sampling produced the least accurate estimators and presented slower responses to variation in phytosociological parameters.
\end{abstract}

KEYWORDS: forestry, sampling procedures, volume stocks, error decay rate

\section{Avaliação de processos de inventário florestal em uma floresta sob concessão na Amazônia brasileira}

\section{RESUMO}

O procedimento de inventário florestal é considerado de alta importância no que concerne estudos de estoque madeireiro, estrutura e diversidade florestal, que fornecem informaçóes relevantes para políticas públicas, planos de manejo e pesquisas ecológicas. O presente trabalho buscou avaliar o desempenho de técnicas de inventário na região Amazônica para estimativa de estoques madeireiros com maior nível de acurácia, mantendo a intensidade amostral fixa. Dois processos de amostragem foram avaliados: amostragem aleatória simples e amostragem em dois estágios. Esses processos foram avaliados através de alocação de unidades amostrais com dimensóes distintas, e os estimadores gerados foram analisados em função da densidade de árvores e da área basal. A amostragem aleatória simples produziu os menores erros, alcançando 9\% quando todas as espécies foram amostradas conjuntamente, e mostrou-se mais eficiente na detecção de variaçóes em parâmetros fitossociológicos. A amostragem em dois estágios produziu os estimadores menos acurados e apresentou respostas mais lentas às variaçóes em parâmetros fitossociológicos.

PALAVRAS-CHAVE: mensuração florestal, processos de amostragem, estoques volumétricos, taxa de decaimento do erro

\section{INTRODUCTION}

The rich composition of plant species in Amazonian forests is not completely elucidated and much remains unknown (Steege et al. 2013). In this scenario, both ecologists and foresters need to make use of sampling techniques to study forest structure in terms of biodiversity, wood production and biomass stocks, which provide relevant information to the execution of management plans, ecological research and public policies (Barros Cavalcanti et al. 2009; Vilà et al. 2013; Cysneiros et al. 2017; Li et al. 2018).
As far as the evaluation of forest structure is concerned, forest survey processes are of the utmost importance for data acquisition, since a true inventory, i.e. the enumeration of all trees in the target area, is not always feasible due to operational limitations (Scolforo and Mello 1993). Such survey processes involve a number of statistical techniques and methods used to estimate important forest parameters with well-delimited errors (Scolforo and Mello 1993; Sanquetta et al. 2014; Péllico Netto et al. 2017). In this scenario, a commendable forest inventory is reached through a good sampling process choice. 
Forest inventories in tropical forests tend to display great errors in tree variable estimations, mainly due to the heterogeneity and complexity of the spatial distribution of species, particularly those with low density (Ubialli et al. 2009). In the Amazon region, where forest growth must be monitored after implementation of sustainable management plans, continuous forest inventories are executed through the allocation of permanent sampling plots and requires precise confidence intervals for parameter estimations (Sanquetta et al. 2014).

Sampling in clusters has been introduced based on the assumption that random samples could be merged together with the aim to reduce displacement costs and overcome operational limitations (Queiroz et al. 2011). The Maltese cross unit technique, which is a case of the two-stage cluster sampling, introduced by Péllico Netto and Brena (1997), has become a cornerstone in Brazilian national forest inventory methodology (Sanquetta et al. 2014). Studies focusing on the comparison of different sampling techniques are scarce (Ubialli et al. 2009; Motz et al. 2010; Dalla Corte et al. 2013; Baraloto et al. 2013; Péllico Netto et al. 2017), yet they are paramount to the identification of techniques best suited for data exploitation in tropical forests, with far-reaching consequences for the efficacy of public policies and strategies for forest stock management, as well as for ecological research of species of interest (Péllico Netto et al. 2017).

We aimed at assessing the precision of two forest inventory processes with respect to variation in sampling plot size in an area of Amazon forest. We hypothesized that relative sampling errors differ between sampling processes, showing an inverse relationship with stand density and basal area. The estimators were adjusted to predict wood volume per unit of area and the precision of estimators was evaluated for the sampling of 12 tropical species.

\section{MATERIAL AND METHODS}

\section{Study area}

The research area is located in Jamari National Forest (Jamari NF), in the north of the state of Rondonnia, in the southwestern Brazilian Amazon, between 09 $00^{\prime} 00^{\prime \prime} \mathrm{S}$ and $09^{\circ} 30^{\prime} 00^{\prime \prime} \mathrm{S}$, and $62^{\circ} 44^{\prime} 05^{\prime \prime} \mathrm{W}$ and $63^{\circ} 16^{\prime} 64^{\prime \prime} \mathrm{W}$, with a total area of approximately 220,000 hectares. The regional climate is classified as $\mathrm{Kw}$ with a well-defined dry period in winter, in accordance with the Köppen system. The mean annual precipitation is $2,400 \mathrm{~mm}$ with a mean annual temperature of $25^{\circ} \mathrm{C}$ (Cysneiros et al. 2016). The Jamari NF is the first to be under concession in Brazil, with an area of approximately 96,000 hectares currently under sustainable management by private companies, while the remaining area is destined to conservation and use by traditional populations (Amata 2013).

\section{Data acquisition}

We assessed an area of 1,926.71 hectares within the Jamari $\mathrm{NF}$ area under concession in which a census for all trees with diameter at breast height greater than $40 \mathrm{~cm}$ was carried out in 2014-2015, before harvesting (Cysneiros et al. 2016). All trees were georreferenced. The twelve most explored species were selected, comprising 6,404 individuals (Table 1). All spatial data were analyzed using $\operatorname{ArcMap}^{\mathrm{TM}} 10.5$ software by Esri. ArcMap ${ }^{\mathrm{TM}}$ is the intellectual property of $\mathrm{Esri}^{\odot}$ and is used herein under license.

\section{Data processing}

We aimed at assessing and comparing simple random sampling (SRS) and two-stage cluster sampling (TSCS) (Figure 1) with the methodology of the Brazilian National Forest Inventory (IFN in Portuguese) for estimation of wood volume in

Table 1. Main timber species exploited in the concession area of Jamari National Forest (Rondônia state, southwestern Brazilian Amazon), indicating their respective basal area and stand density in the inventory area used to run sampling simulations.

\begin{tabular}{lcc}
\hline Species & $\begin{array}{c}\text { Basal area } \\
\left(\mathrm{m}^{2} \mathrm{ha}^{-1}\right)\end{array}$ & $\begin{array}{c}\text { Stand density } \\
(100 \text { trees ha-1) }\end{array}$ \\
\hline Peltogyne paniculata Benth. & 0.2654 & 83.1 \\
\hline Caryocar glabrum Pers. & 0.0884 & 18.7 \\
Brosimum rubescens Taub. & 0.0600 & 14.9 \\
Astronium lecointei Ducke. & 0.2861 & 67.4 \\
Clarisia racemosa Ruíz \& Pav. & 0.1082 & 33.1 \\
Apuleia leiocarpa (Vogel) J.F.Macbr. & 0.0293 & 4.6 \\
Couratari stellata A. C. Sm. & 0.1761 & 30.2 \\
Goupia glabra Aubl. & 0.0951 & 17.8 \\
Dipteryx odorata (Aubl.) Willd. & 0.0915 & 21.1 \\
Qualea paraensis Ducke. & 0.0624 & 18.4 \\
Hymenolobium heterocarpum Ducke. & 0.1413 & 23.8 \\
Dinizia excelsa Ducke. & 0.5903 & 51.3 \\
\hline
\end{tabular}

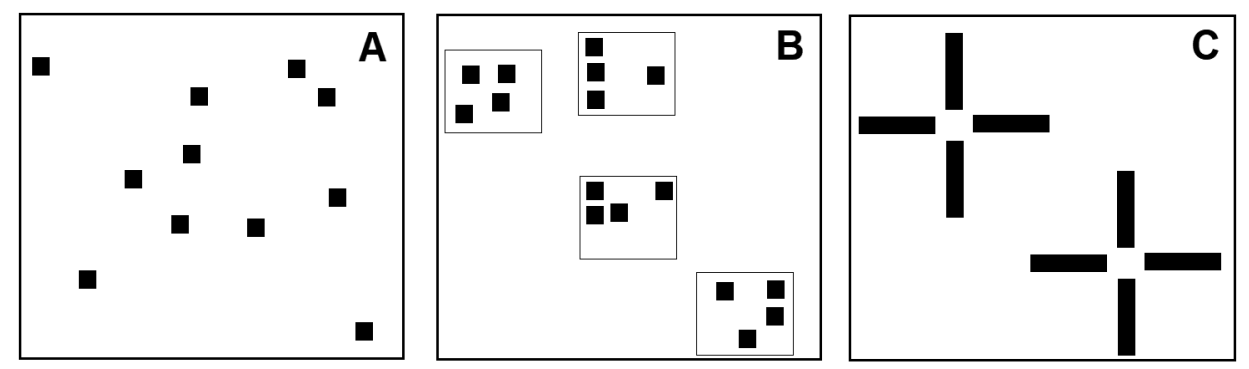

Figure 1. Sampling plot distribution design of sampling processes used in the simulations performed on census data from a sustainable management forest area in Jamari National Forest, southwestern Brazilian Amazon. A - simple random sampling; B - two-stage cluster sampling; C - two-stage cluster sampling with a Maltese cross unit. 
Amazonian Forest inventories. For the SRS four different rectangular sampling unit sizes were used: $2,000 \mathrm{~m}^{2}(20 \times 100$

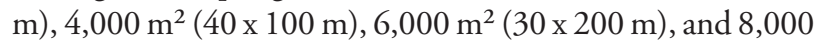
$\mathrm{m}^{2}(40 \times 200 \mathrm{~m})$. The same unit sizes were used for the TSCS, but the primary unit was fixed in a square area of $40,000 \mathrm{~m}^{2}$. The IFN method is performed in clusters through the Maltese cross unit methodology (Figure 1), with subunits of 8,000 $\mathrm{m}^{2}(40 \times 200 \mathrm{~m})$ and was compared to the SRS and TSCS processes in the present study (Table 2 ). The simulations were conceived with the aid of $\operatorname{ArcMap}^{\mathrm{TM}}$ for a sampling intensity of $10 \%$ of the total area. Further information about the sampling processes are available in Sanquetta et al. (2014).

Sampling processes were applied for estimation of wood volume for individual species as well as for all species combined, and the corresponding relative sampling errors associated with the sampling estimates were computed (for a detailed description of computations and formulae see Sanquetta et al. 2014). All errors were computed within a 95\% confidence interval and the error limit set at $10 \%$.

In order to further analyze sampling accuracy, errors were weighted according to species density by multiplying the relative sampling error by the number of individuals of a particular species and then dividing this product by the total number of individuals in the sampling area. The weighted relative sampling error is a measure of the inventory estimators' accuracy at the species level, and therefore the behavior of the estimators is not analyzed only with respect to the population, but rather expresses their effectiveness when singular species are considered. The mean of the weighted relative sampling error is given by:

$$
\overline{e_{w}}=\frac{1}{n} \sum_{i=1}^{n}\left(e_{w i}\right)
$$

where $e_{w}$ denotes the weighted relative sampling error of a particular species, $n$ the number of species, and $\overline{e_{w}}$ the weighted mean sampling error.

Table 2. Summary of sampling parameters used in simulations of three inventory processes using data from a sustainable management forest area in Jamari National Forest, southwestern Brazilian Amazon. N plots = number of plots for a $10 \%$ sampling intensity.

\begin{tabular}{lcc}
\hline Sampling process & $\begin{array}{c}\text { Sampling plot size } \\
\left(\mathrm{m}^{2}\right)\end{array}$ & N plots \\
\hline \multirow{2}{*}{ Simple random sampling (SRS) } & 2,000 & 964 \\
& 4,000 & 482 \\
\hline & 6,000 & 321 \\
\hline Two-stage cluster sampling (TSCS) & 8,000 & 241 \\
\hline Maltese cross unit (IFN) & 2,000 & 964 \\
\hline
\end{tabular}

Weighted relative sampling errors were compared among the sampling processes using Analysis of Variance (ANOVA). Fisher's Least Square Difference (LSD) post-hoc test was used performed so as to identify which means diverged.

Linear regression models were fitted to the log-transformed data to analyze the behavior of the relative sampling error as a function of stand density and basal area. By definition, the regression slope corresponds to the tangent of the line generated by the fitting of the linear regression on the data. Means of slopes were calculated for SRS and TSCS, since only these processes varied in terms of sample size. Data were treated in Excel and R Studio 3.4.1 (R Core Team 2017) and graphs were made using the package ggplot2 (Wickham 2009).

\section{RESULTS}

The weighted relative sampling error means differed significantly among the sampling processes (ANOVA, $\mathrm{p}=$ $\left.8.25 \times 10^{-28}\right)$. TSCS differed significantly from the other processes (Fischer LSD) and had the highest mean values for weighted relative sampling errors (Figure 2). Although the weighted relative sampling error of SRS and IFN did not differ statistically, the error for SRS was smaller than for IFN, particularly when all species were sampled together. The relative sampling error ranged from $9 \%$ for SRS using 2,000 $\mathrm{m}^{2}$ to $21.7 \%$ for IFN using $8,000 \mathrm{~m}^{2}$ (Table 3).

The relative sampling error was significantly correlated with stand density in all cases $\left(\mathrm{R}^{2}>0.85, \mathrm{p}<0.05\right)$. The linear regression models for stand density (Figure 3) had a mean negative slope of -0.4624 , with a standard deviation of 0.0348 . The relative sampling error had a weaker, but still significant relationship with basal area in all cases $(\mathrm{p}<0.05)$. The linear regression models for basal area (Figure 4) had a mean negative slope of -0.3756 , with a standard deviation of 0.0347 .

Table 3. Mean weighted relative sampling error, mean relative sampling error and relative sampling error for all species combined for sampling simulations with three forest inventory methods (simple random sampling, SRS; two-stage cluster sampling, TSCS; Maltese cross unit, IFN) and different sampling plot sizes (2000, 4000, 6000 and $8000 \mathrm{~m}^{2}$ ) using data from a sustainable management forest area in Jamari National Forest, southwestern Brazilian Amazon. Values are the mean \pm standard deviation.

\begin{tabular}{lccc}
\hline Method/plot size & $\begin{array}{c}\text { Mean weighted } \\
\text { relative SE (\%) }\end{array}$ & $\begin{array}{c}\text { Mean relative SE } \\
(\%)\end{array}$ & $\begin{array}{c}\text { Relative SE all } \\
\text { species (\%) }\end{array}$ \\
\hline SRS 2,000 & $2.14 \pm 0.88$ & $32.40 \pm 13.07$ & 9.04 \\
SRS 4,000 & $2.81 \pm 1.10$ & $43.24 \pm 19.29$ & 8.25 \\
SRS 6,000 & $2.56 \pm 0.90$ & $34.68 \pm 15.43$ & 7.74 \\
SRS 8,000 & $2.23 \pm 0.95$ & $33.84 \pm 15.04$ & 10.38 \\
\hline TSCS 2,000 & $17.29 \pm 7.24$ & $26.91 \pm 0.88$ & 74.74 \\
TSCS 4,000 & $8.57 \pm 3.06$ & $133.94 \pm 121.11$ & 25.68 \\
TSCS 6,000 & $5.15 \pm 2.31$ & $75.58 \pm 61.18$ & 15.06 \\
TSCS 8,000 & $4.38 \pm 1.82$ & $65.31 \pm 27.19$ & 21.74 \\
IFN 8,000 & $2.77 \pm 1.29$ & $41.05 \pm 16.88$ & 21.74 \\
\hline
\end{tabular}




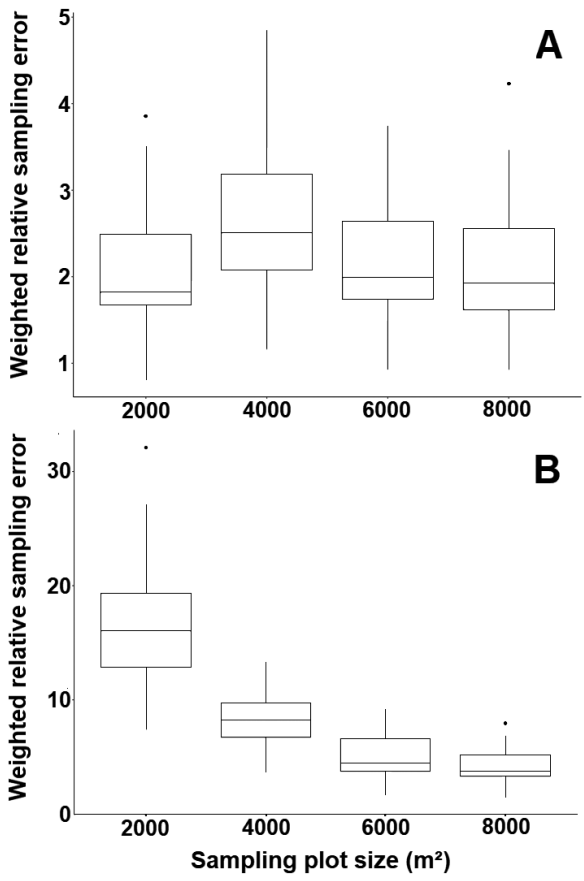

Figure 2. Weighted relative sampling errors as a function of sampling plot size used in inventory simulations for different sampling methods on data from a sustainable management forest area in Jamari National Forest, southwestern Brazilian Amazon. A - Simple Random Sampling. B - Two Stage Cluster Sampling.

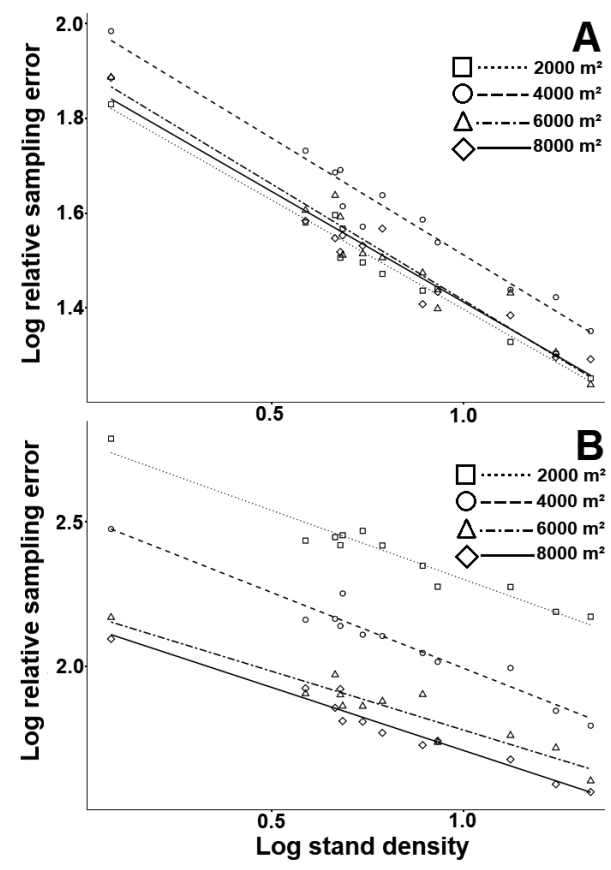

Figure 3. Linear regression models of the relative sampling error as a function of stand density for simulated samplings on data from a sustainable management forest area in Jamari National Forest, southwestern Brazilian Amazon. A - simple random sampling [sampling plot sizes of $2000 \mathrm{~m}^{2}\left(\mathrm{R}^{2}=0.98, p=1.51 \times 10^{-9}\right), 4000$ $\mathrm{m}^{2}\left(\mathrm{R}^{2}=0.96, p=1.42 \times 10^{-8}\right), 6000 \mathrm{~m}^{2}\left(\mathrm{R}^{2}=0.94, \mathrm{p}=1.42 \times 10^{-7}\right)$, and $8000 \mathrm{~m}^{2}$ $\left.\left(R^{2}=0.95, p=4.7 \times 10^{-3}\right)\right]$. $B$ - two-stage cluster sampling [sampling plot sizes of $2,000 \mathrm{~m}^{2}\left(R^{2}=0.94, p=8.77 \times 10^{-8}\right), 4000 \mathrm{~m}^{2}\left(R^{2}=0.95, p=7.73 \times 10^{-8}\right), 6000 \mathrm{~m}^{2}$ $\left(R^{2}=0.89, p=2.98 \times 10^{-6}\right)$, and $\left.8000 m^{2}\left(R^{2}=0.95, p=4.12 \times 10^{-8}\right)\right]$.

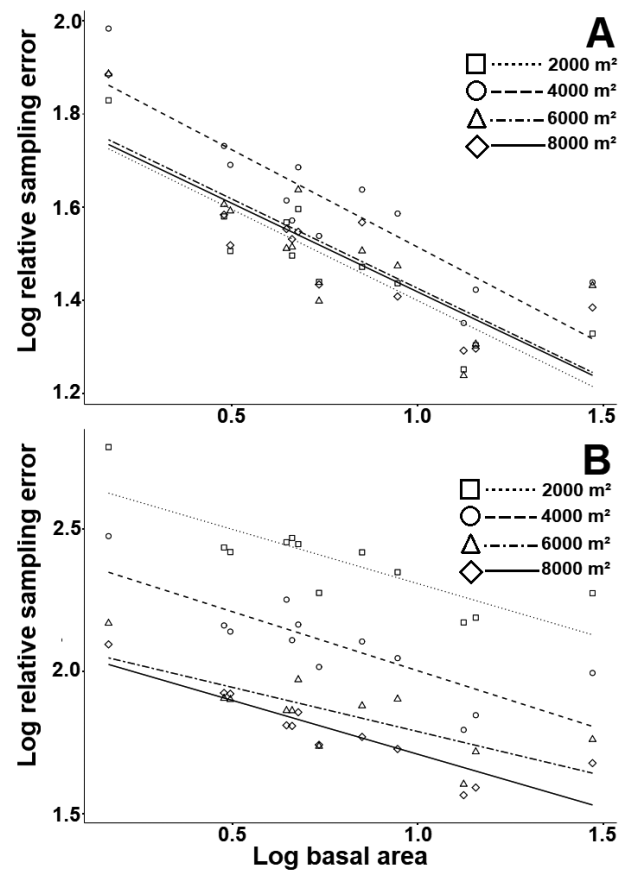

Figure 4. Linear regression models of the relative sampling error as a function of basal area for simulated samplings on data from a sustainable management forest area in Jamari National Forest, southwestern Brazilian Amazon. A - simple random sampling [sampling plot sizes of $2000 \mathrm{~m}^{2}\left(R^{2}=0.77, p=1.1 \times 10^{-4}\right), 4000$ $\mathrm{m}^{2}\left(\mathrm{R}^{2}=0.76, p=1.5 \times 10^{-4}\right), 6000 \mathrm{~m}^{2}\left(\mathrm{R}^{2}=0.61, \mathrm{p}=1.6 \times 10^{-3}\right)$, and $8000 \mathrm{~m}^{2}\left(\mathrm{R}^{2}=\right.$ $\left.0.68, p=4.6 \times 10^{-3}\right)$ ]. $B$ - two-stage cluster sampling [sampling plot sizes of 2000 $\mathrm{m}^{2}\left(R^{2}=0.65, p=9.70 \times 10^{-4}\right), 4000 \mathrm{~m}^{2}\left(R^{2}=0.64, p=1.17 \times 10^{-3}\right), 6000 \mathrm{~m}^{2}\left(R^{2}=\right.$ $\left.0.54, p=3.77 \times 10^{-3}\right)$, and $\left.8000 \mathrm{~m}^{2}\left(R^{2}=0.79, p=7.54 \times 10^{-5}\right)\right]$.

\section{DISCUSSION}

Low-density species tend to generate higher sampling errors in inventories process (Machado 1988; Ubialli et al. 2009; Péllico Netto et al. 2017). To date, no modelling had been applied to relative sampling error as a function of stand density and basal area. Our results showed that the relative sampling error, which is intrinsic to the inventory procedure, decreases at a well-defined rate as stand density and basal area increase. The regression slopes of the relative sampling error as a function of stand density indicated that the effectiveness of estimators is more sensitive to the number of trees per area unit than to the basal area per unit of area, possibly because the probability of sampling a species in a plot increases with species density. This points to the fact that precisions estimates may differ among inventory processes depending on the degree of site disturbance, since increasing extraction of timber and rotting of boles alter stand density and basal area (Sagar and Singh 2006; Reis et al. 2014). Therefore it is relevant to know how the relative sampling error of a particular inventory process behaves in relation to stand density and basal area.

As the weighted relative sampling error is a measure of the deviations at species level, it is reasonable to expect that interspecific variations in density accounted for the 
interspecific deviations in the errors, leading to differential performance of the estimators. The spatial distribution pattern of species (whether populations are aggregate and sparse) may significantly influence the accuracy of sampling estimators. Adaptive cluster sampling has been used in an attempt to increase the frequency of non-zero plots, i.e. plots with at least one sampled tree of that species (Péllico Netto et al. 2017). However, although relative sampling error was decreased significantly for some species, adaptive cluster sampling seemed to be as sensitive to stand density as the traditional sampling processes tested in here.

Our results show that SRS was associated with the lowest errors, independently of the sampling plot size. Furthermore, SRS relative error seemed to decrease more rapidly with the increase in stand density and basal area than did the error of TSCS. This indicates that SRS might be more accurate in capturing phytosociological variations among inventories. The greater error levels in TSCS when all species were sampled together was likely due to the fact that the variance is higher within than among clusters. However, if this is the case, it might be assumed that spatial dependence occurs at a larger scale than can be detected by the clustering of samples, as the similarity between ecosystem elements decreases with distance (Miller et al. 2007) and vegetation is therefore not randomly distributed. Further studies are needed to evaluate the effect of distance among sampling units on forest inventory sampling errors.

In Europe mixed forests are, on average, $24 \%$ more productive than monospecific forests, and the positive association between species richness and wood production is mediated by the increase in stand basal area (Vilà et al. 2013). The variance of wood production in relation to tree species richness can influence sampling error and, in the Amazon basal area and stand density seem to influence estimates of wood volume as well (Cysneiros et al. 2016). We thus propose that sampling procedures in tropical forests should be carried out in two steps: first, a pre-sampling is carried out to determine spatial dependence of forest phytosociological parameters, and, in a second step, sampling plots are deployed in accordance with the strata generated by the pre-sampling. This procedure needs to be associated with an evaluation of economic viability of the procedure, since cost optimization with respect to the required accuracy is one of the main drivers of forest inventory planning (Queiroz 2012).

\section{CONCLUSIONS}

Simple random sampling (SRS) had a better performance than two-stage cluster sampling (TSCS), including its variant using the Maltese cross unit, when tested on census data from a sustainable management forest area in Jamari National Forest, in the southwestern Brazilian Amazon. Relative sampling errors and weighted relative sampling errors were lower for
SRS, which also seemed to be more sensitive to variations in phytosociological parameters, such as stand density and basal area, as indicated by the the slopes of adjusted linear regression models. We suggest that SRS may be a better technique to sample complex forest structures such as those of Amazon forests, and the evaluation of spatial dependency of variables should be included in forest inventory processes.

\section{ACKNOWLEDGMENTS}

The authors would like to thank the Conselho Nacional de Desenvolvimento Científico e Tecnológico (CNPq) for granting a scholarship to Felipe Kauai for the development of this work and Amata S.A for providing the database used in the present work. In addition, we acknowledge the BIOFIX Excellence Research Center on Carbon Sink in Biomass (Universidade Federal do Paraná - UFPR) for supporting the project.

\section{REFERENCES}

Amata. 2013. Plano Operacional Anual 03. 2013. Unidade de Manejo Florestal III - Floresta Nacional do Jamari, Unidade de Produção Anual 03 - 2012/2013. Amata S.A., Technical report, 312p.

Barros Cavalcanti, F.J.; Machado, S.D.A.; Hosokawa, R.T. 2009. Tamanho de unidade de amostra e intensidade amostral para espécies comerciais da Amazônia. Floresta, 39: 207-214.

Baraloto, C.; Molto, Q.; Rabaud, S.; Hérault, B.; Valencia R.; Blanc, L.; Thompson, J. 2013. Rapid simultaneous estimation of aboveground biomass and tree diversity across Neotropical forests: a comparison of field inventory methods. Biotropica, 45: 288-298.

Cysneiros, V.C.; Machado, S.D.A.; Pelissari, A.L.; Figueiredo Filho, A.; Urbano, E. 2016. Modeling of the commercial volume stock in an Ombrophilous Forest in the Southwest of the Amazon. Cerne, 22: 457-464.

Cysneiros, V.C.; Pelissari, A.L.; Machado, S.D.A.; Figueiredo Filho, A.; David, H.C. 2017. Cluster and discriminant analyses for stem volume modelling of tree species groups in an amazon rainforest. Journal of Tropical Forest Science, 29: 325-333.

Dalla Corte, A.P.; Sanquetta, C.R.; Figueiredo Filho, A.; Pereira, R.K.; Behling, A. 2013. Desempenho de métodos e processos de amostragem para avaliaçáo de diversidade em Floresta Ombrófila Mista. Floresta, 43: 579-592.

Li, S.; Lang, X.; Liu, W.; Ou, G.; Xu, H.; Su, J. 2018. The relationship between species richness and aboveground biomass in a primary Pinus kesiya forest of Yunnan, southwestern China. PloS one, 13: e0191140.

Machado, S.D.A. 1988. Complete enumeration forest inventory versus cluster sampling method applied in the Amazonic rain forest. Floresta, 18: 122-130.

Miller, J.; Franklin, J.; Aspinall, R. 2007. Incorporating spatial dependence in predictive vegetation models. Ecological Modelling, 202: 225-242.

Motz, K.; Sterba, H.; Pommerening, A. 2010. Sampling measures of tree diversity. Forest Ecology Management. 260: 1985-1996. 
Péllico Netto, S.; Brena, D.A. 1997. Inventário Florestal. Universidade Federal do Paraná, Curitiba, 316p.

Péllico Netto, S.; Pelissari, A.L.; Cysneiros, V.C.; Bonazza, M.; Sanquetta, C.R. 2017. Sampling procedures for inventory of commercial volume tree species in Amazon Forest. Anais da Academia Brasileira de Ciências, 89: 1829-1840.

Queiroz, W.T.; Péllico Netto, S.; Valente, M.D.R.; Pinheiro, J.G. 2011. Análise Estrutural da Unidade Conglomerada Cruz de Malta na Floresta Nacional do Tapajós, Estado do Pará, Brasil. Floresta, 41: 9-18.

Queiroz, W.T. 2012. Amostragem em inventário florestal. Edufra, Universidade Federal Rural da Amazônia, Belém, 441p.

R Development Core Team. 2017. R: A language and environment for statistical computing. R Foundation for Statistical Computing, Vienna, Austria. URL: (http://www.R-project.org/).

Reis, P.C.M.D.; Reis, L.P.; Ruschel, A.R.; Silva, J.N.M.; Carvalho, J.O.P.D.; Queiroz, W.T.D. 2014. Effect of timber harvesting on density and basal area of Lecythidaceae species in the Eastern Amazon. Floresta, 44: 229-238.

Sagar, R.; Singh, J.S. 2006. Tree density, basal area and species diversity in a disturbed dry tropical forest of northern India: implications for conservation. Environmental Conservation, 33: 256-262.
Sanquetta, C.R.; Dalla Corte, A.P.; Rodrigues, A.L.; Watzlawick, L.F. 2014. Inventários florestais: planejamento e execução. 3th ed. Multi-Graphic Gráfica e Editora, Curitiba, 406p.

Scolforo, J.R.S.; Mello, J.D. 1993. Inventário florestal. ESAL-FAEPE, Lavras, 228p.

Steege, H.T.; Pitman, N.C.A.; Sabatier, D.; Baraloto, C.; Salomão, R.P.; Guevara, J.E. et al. 2013. Hyperdominance in the Amazonian Tree Flora. Science, 342: 324-334.

Ubialli, J.A.; Figueiredo Filho, A.; Machado, S.D.A.; Arce, J.E. 2009. Comparação de métodos e processos de amostragem para estimar a área basal para grupos de espécies em uma floresta ecotonal da região norte matogrossense. Acta Amazonica, 39: 305-314.

Vilà, M.; Carrillo-Gavilán, A.; Vayreda, J.; Bugmann, H.; Fridman, J.; Grodzki, W. et al. 2013. Disentangling biodiversity and climatic determinants of wood production. PloS ONE, 8: e53530.

Wickham, H. 2009. Ggplot2: Elegant Graphics for Data Analysis. Springer-Verlag, New York. 224p.

RECEIVED: $26 / 05 / 2018$

ACCEPTED: $15 / 10 / 2018$

ASSOCIATE EDITOR: Francesco Ripullone 